\title{
Fishermen Local Knowledge and Aquatic Environmental Change: Impacts on Fishing and Adaptation Strategies in Volta Basin
}

\author{
Rimwaodo Pierre Silga1* , Adama Oueda1, Winkom Noellie Kpoda1, Komandan Mano², \\ Idrissa Ouedraogo ${ }^{3}$, D. M. Peter Weesie ${ }^{4}$, Boureima Gustave Kabre ${ }^{1}$ \\ ${ }^{1}$ Life and Earth Sciences Training and Research Unit, University Joseph Ki-Zerbo, Ouagadougou, Burkina Faso \\ ${ }^{2}$ Applied Sciences and Technology Training and Research Unit, University of Dédougou, Dédougou, Burkina Faso \\ ${ }^{3}$ University of Dori, Dori, Burkina Faso \\ ${ }^{4}$ Sciences and Society Group (SSG), University of Groningen, Groningen, Netherlands \\ Email: ^pirelrelwender@gmail.com, oueda14@yahoo.fr, kpodaw@yahoo.fr, manokomandan82@gmail.com, \\ o.idrissa16@gmail.com,p.d.m.weesie@rug.nl,gkabre2@gmail.com
}

How to cite this paper: Silga, R.P., Oueda, A., Kpoda, W.N., Mano, K., Ouedraogo, I., Weesie, D.M.P. and Kabre, B.G. (2021) Fishermen Local Knowledge and Aquatic Environmental Change: Impacts on Fishing and Adaptation Strategies in Volta Basin. Open Journal of Ecology, 11, 507-526. https://doi.org/10.4236/oje.2021.117033

Received: June 1, 2021

Accepted: July 16, 2021

Published: July 19, 2021

Copyright $\odot 2021$ by author(s) and Scientific Research Publishing Inc. This work is licensed under the Creative Commons Attribution International License (CC BY 4.0).

http://creativecommons.org/licenses/by/4.0/

(c) (i) Open Access

\begin{abstract}
Climate researches predict that climate change will have an important impact on aquatic and terrestrial ecosystems. However, many fishermen do not have a lot of knowledge about climate change or how it might affect their fish catch yields and overall fishing operations in the future. The objective of this study was to assess local fishermen's perception of global change on the ichthyofauna of the Volta Basin in Burkina Faso. Focus group interviews were conducted between March 2019 and July 2020 in 19 reservoirs of the Volta Basin. A total of 242 fishermen divided into 34 groups participated in the interviews. The results showed that fishermen are aware of climatic and anthropogenic threats to fish fauna. According to them, these global changes lead to important modifications in the structure of the ichthyofauna ranging from seasonal mortality of fish (Mormyridae) to the extinction of certain species such as those of the genera Lates, Hydrocynus and Heterotis. These changes also lead to a loss of fish habitat through silting and lower water levels in the reservoirs. Statistical analysis of the collected data showed that the main factors threatening the structure and dynamics of fish are mainly agriculture and market gardening around the dam lakes, the temperature increase and the trend of decreasing rainfall. Thus, the main pressures responsible for the mortality and/or extinction of fish are market gardening pollution (100\%), bad fishing practices (63.15\%) and high temperatures (47.5\%). As for adaptation measures and management strategies, the most important were training and sensitization of stakeholders (78.94\% of citations) followed by fish stocking (21.05\%). This endogenous knowledge is important for the development of climate
\end{abstract}


change adaptation programs.

\section{Keywords}

Climate Variability, Perception, Fishing, Burkina Faso

\section{Introduction}

Changes in climatic and environmental conditions today constitute threat to local populations in Burkina Faso [1] and to the survival of biodiversity [2] with a certain ecological impact [3]. According to the IPCC [4], these climate changes are likely to compromise ecosystems' sustainability and their services. Worldwide, fishery resources contribute more than $10 \%$ of the animal's protein ration for about 4 billion people [5]. In Africa, fish is the main source of animal protein for rural populations [6]. In Burkina Faso, it contributes to about $8 \%$ of the protein coverage of food needs and $3 \%$ of gross domestic product (GDP) [7]. In addition, we note that the landlocked position of Burkina Faso and the sources of its economy which are essentially based on agriculture make it even more vulnerable to climate change. Thus, activities such as fishing whose productivity is strongly influenced by climatic variables like rainfall and temperature are threatened by these global changes. An additional factor is the non-compliance with fishing regulations [8]. A reduction in fishery production risks jeopardizing the achievement of the Sustainable Development Goals (SDGs) by impacting its Goal2 which is to "...End hunger, achieve food security and improve nutrition, and promote sustainable agriculture". However, climatic hazards, in addition to population growth, may weigh more heavily on ecosystem services. Indeed, the modification of fish habitats due to climatic and environmental hazards such as irregular rainfall, rising temperature, anthropogenic activities, extreme weather conditions will have a negative impact on the size of fish and their geographic distribution [3] [9]. Several studies have already addressed the perception of environmental and climate change by local communities [10] [11] [12], but very few were interested in the way it is perceived by fishing communities. However, for a sustainable management of fisheries, it is important to better understand how fishermen perceive the effect of different pressures on fish and their habitat. In Burkina Faso, according to statistics from the Ministry in charge of Fisheries Resources, fish production has increased since the 2000s despite the decrease in fish catch per fisherman. This implicitly indicates an increase in the number of fishermen. According to some authors, this decline could be explained by the effect of anthropogenic pressures [13]. By the past, many studies have shown that local people possess endogenous knowledge and strategies to manage sustainably their natural resources [14]. For other authors, local actors often ignore the ecological problems generated by climate change [15]. In addition, insufficient knowledge of the fisheries creates uncertainties related to the quantity and qual- 
ity of the catches [5] and constitutes a factor limiting the sustainable management of the fishery [16]. This work answers the following research question: "What understanding do local fishermen have of anthropogenic and climatic pressures influence on fish fauna in Burkina Faso?" To answer this question, we hypothesized that fishermen, as the first direct actors of fishing, could have interesting information on the nature and intensity of environmental and climatic pressures affecting fish fauna, on the one hand, and could develop best strategies to adapt themselves to environmental change, on the other hand. This work's general objective is to assess the perception of environmental and climatic changes by direct actors, namely local fishermen in the Volta basin fishery in Burkina Faso. To achieve this, specific objectives have been defined: 1) identify the different pressures likely to have an impact on fish diversity; 2), assess the occurrence of perception of these pressures by fishermen, 3 ) identify the groups or species of fish threatened by these anthropogenic and climatic pressures and 4) determine the local strategies adaptation.

\section{Methodology}

\subsection{Sites of Study}

This study was conducted in nineteen (19) sites of Volta basin in Burkina Faso. This basin is subdivided into two sub-basins (Mouhoun and Nakanbe). The choice of this basin is justified by the fact that it is the basin which has more reservoirs and also the most anthropized basin. This basin covers an area of $106,742 \mathrm{~km}^{2}$ (Figure 1).

Table 1 below presents the environmental characteristics of the 19 study sites. The description of the environment and the climate of the area are presented.

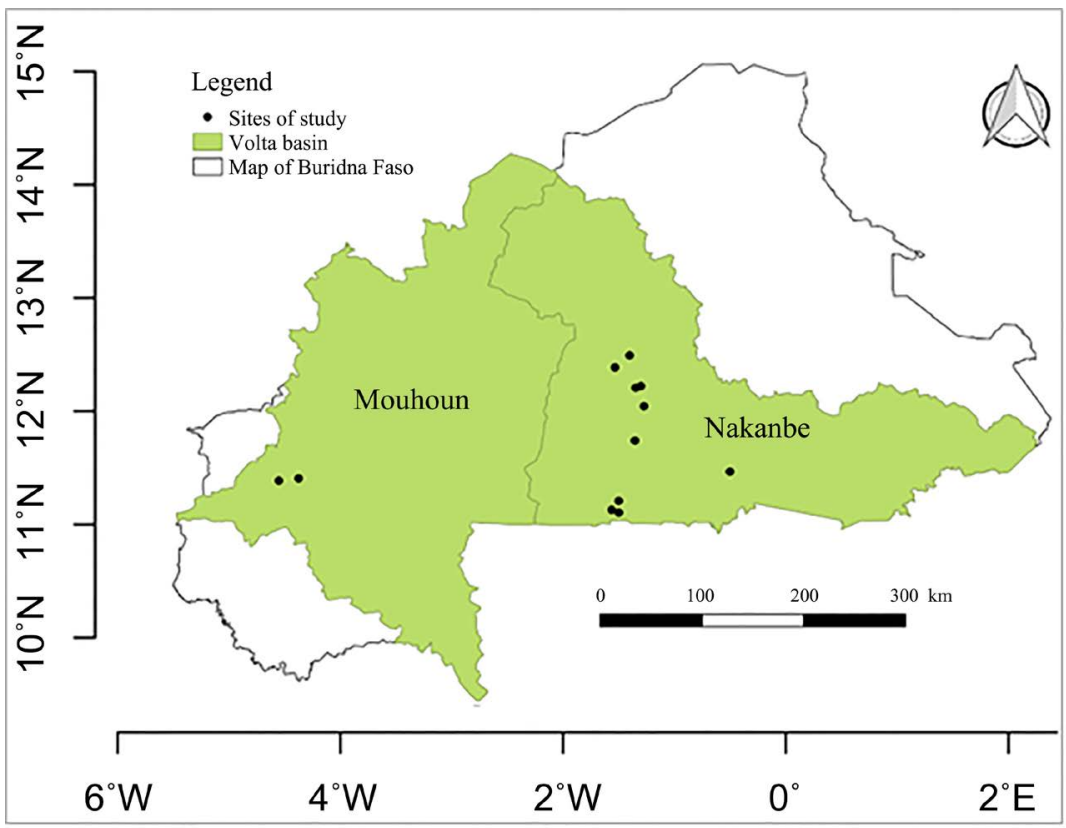

Figure 1. Map of Burkina Faso with study sites. 
Table 1. Environmental characterization of the study sites.

\begin{tabular}{|c|c|c|c|}
\hline Study sites & Sub-basins & Climate & Environment description \\
\hline $\begin{array}{l}\text { Naba Zana, Konioudou, } \\
\text { Arzoum Baongo, Goanghin }\end{array}$ & \multirow{5}{*}{ Nakanbé } & \multirow{5}{*}{$\begin{array}{l}\text { North Sudanian climate with annual rainfall } \\
\text { between } 350 \mathrm{~mm} \text { and } 900 \mathrm{~mm} \text {. These sites } \\
\text { have a low vegetation cover. }\end{array}$} & $\begin{array}{l}\text { Located in the commune of Koubri, these sites are } \\
\text { highly anthropized (agriculture, fishing, silting...). }\end{array}$ \\
\hline Bazega & & & $\begin{array}{l}\text { There is a strong pressure of fishing and pumping for } \\
\text { fruit gardens }\end{array}$ \\
\hline Loumbila, Tanghin & & & $\begin{array}{l}\text { Experience a strong anthropization: fishing, pumping, } \\
\text { market gardening, household activities, silting ... }\end{array}$ \\
\hline Bankako & & & $\begin{array}{l}\text { This site is located in the downstream part of the } \\
\text { Bagré reservoir. Characterized by the cultivation of } \\
\text { rice in irrigation. }\end{array}$ \\
\hline $\begin{array}{l}\text { Dirlakou, Zangoula } \\
\text { Lengha, Koumbouré } \\
\text { Béguédo, Niaogho }\end{array}$ & & & $\begin{array}{l}\text { Located upstream of the Bagré reservoir, these sites } \\
\text { are under strong agricultural pressure. }\end{array}$ \\
\hline $\begin{array}{l}\text { Nazinga (Kalieboulou, } \\
\text { Bodjero, Nakourou) }\end{array}$ & Nakanbé & Vegetation cover of the tree savannah type. & Protected area, controlled fishing. \\
\hline Mare Hippo & & South Sudanese climate. Annual rainfall is & $\begin{array}{l}\text { Protected area, controlled fishing, presence of invasive } \\
\text { plants. }\end{array}$ \\
\hline Samandeni & Mouhoun & $\begin{array}{l}\text { between } 900 \mathrm{~mm} \text { and } 1100 \mathrm{~mm} \text {. Important } \\
\text { vegetation cover with large trees all around. }\end{array}$ & $\begin{array}{l}\text { Created in } 2018 \text {, low agricultural pressure with in- } \\
\text { creasing fishing pressure. }\end{array}$ \\
\hline
\end{tabular}

\subsection{Data Collection}

\subsubsection{Socio-Environmental Data}

The socio-environmental data collection was designed in two steps. The first step consisted of a pre-survey in March 2019. During this step, fishermen from 3 villages (Dirlakou, Dakopa and Zangoula) around the Bagré reservoir have been interviewed in order to test and refine the survey questionnaire. After these interviews a final questionnaire was developed. During the second step, we ran the survey based on the refined questionnaire following the focus group method. Thirty-four focus groups were constituted with 242 fishermen. The information collected were about the: 1) perception of environmental pressures by fishermen on fish fauna; 2) species sensitive to environmental pressures; 3) variables responsible for the variation in water column and 4) adaptation strategies.

\subsubsection{Fish Identification}

In each site, the fish found death were identified to species or genus level using identification keys [17]. Unidentified individuals were performed later by a professional taxonomist in the laboratory.

\subsubsection{Statistical Data Analysis}

The survey data was entered and processed using the Excel spreadsheet and the R Studio interface of the R 4.0.2 software. To define the size and perception of the population studied, frequency and percentage analyses were performed. A Redundancy Analysis (RDA) was carried out in order to identify the explanatory variables responsible for the extinction and mortality of the fish. The statistical test of Kruskal Wallis was carried out using the kruskal.test () function to check 
if there is statistically a significant difference between the pressure indicators expressed by the fishermen on the one hand, and on the other hand between the number of pressures expressed by the different groups of fishermen interviewed. The p-value was set at $5 \%$.

\section{Results}

\subsection{Distribution of Fishermen Interviewed by Age Class}

The fishermen surveyed are men with at least 5 years of fishing experience. Figure 2 presents their distribution in the survey sample by age group. The analysis of this figure shows that the age group that includes the most fishermen questioned is the age group between 16 and 25 years which is represented by $44 \%$.

\subsection{Pressures Perceived by Fishermen}

As a result of the interviews conducted, 23 pressures were cited by the fishermen as being able to cause fish mortality and/or disappearance (Figure 3). The statistical analysis showed that the difference between the frequencies of citations of the different pressures is statistically significant with a p.value $=0.0032$. On the other hand, there was no significant difference between the number of pressures cited by each category of fishermen (p.value $=0.089$ ). The different environmental and climatic pressures perceived by the fishermen of the different sites visited vary in number depending on the site. The highest number is found in the fisheries located in the Nakanbé basin and particularly in the Koubri area.

The results of Figure 4 show the threats to fish based on the experience of the fishermen surveyed. The analysis of this figure shows that fishermen with more

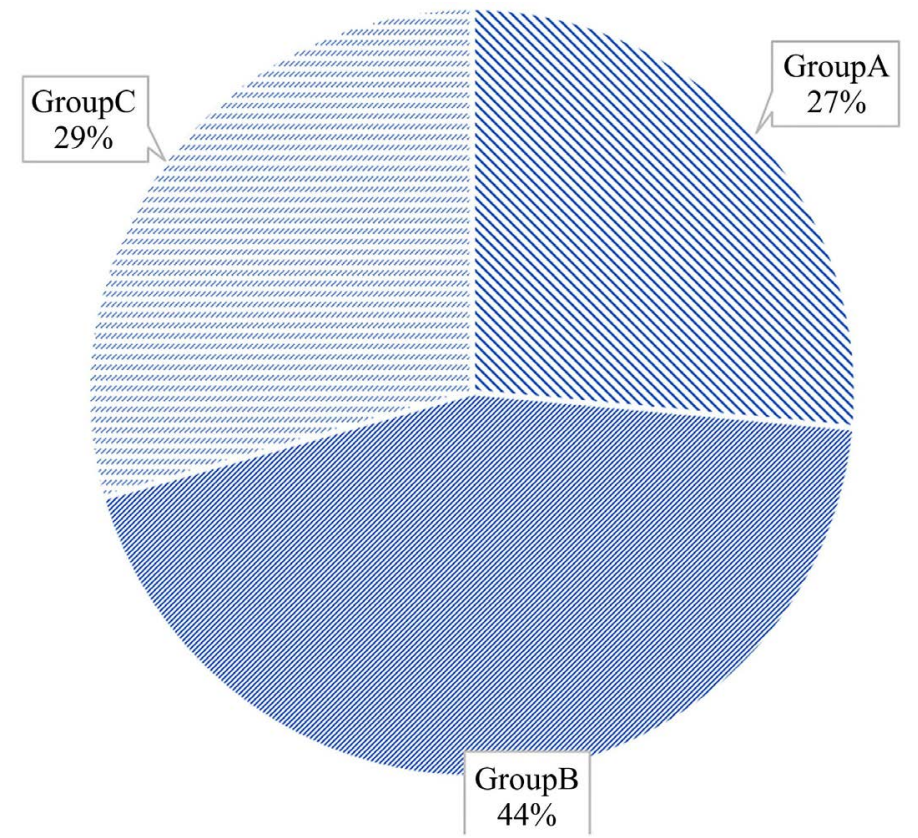

Legend: GroupA: 5-15 years experience; GroupB: $16-25$ years; GroupC: $\geq 26$ years

Figure 2. Distribution of respondents by age group. 


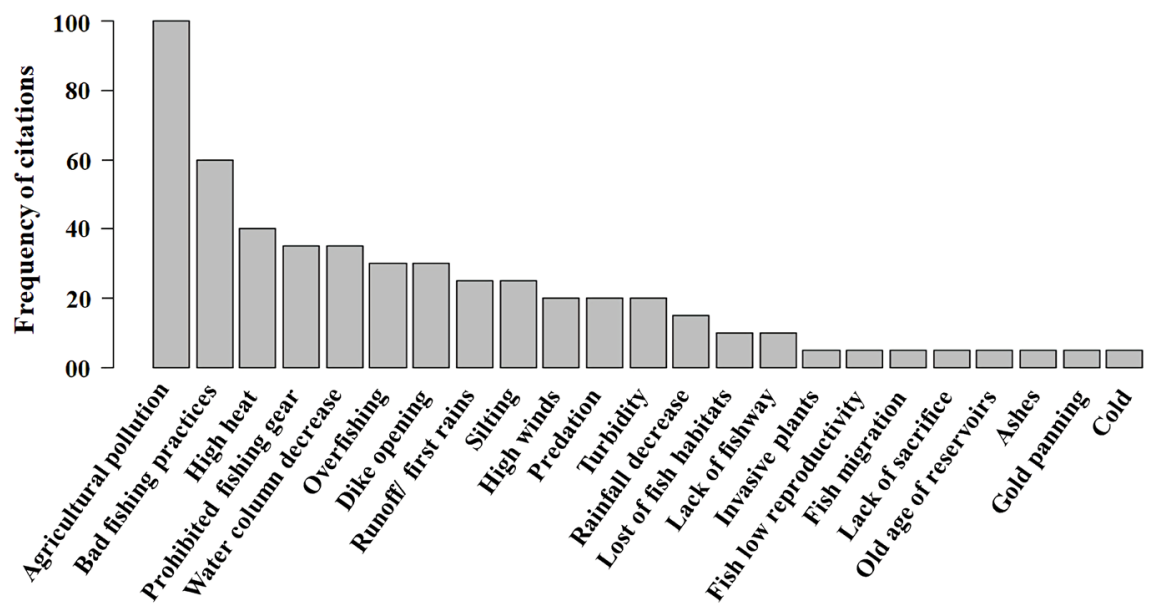

Figure 3. Global pressures perceived by fishermen.

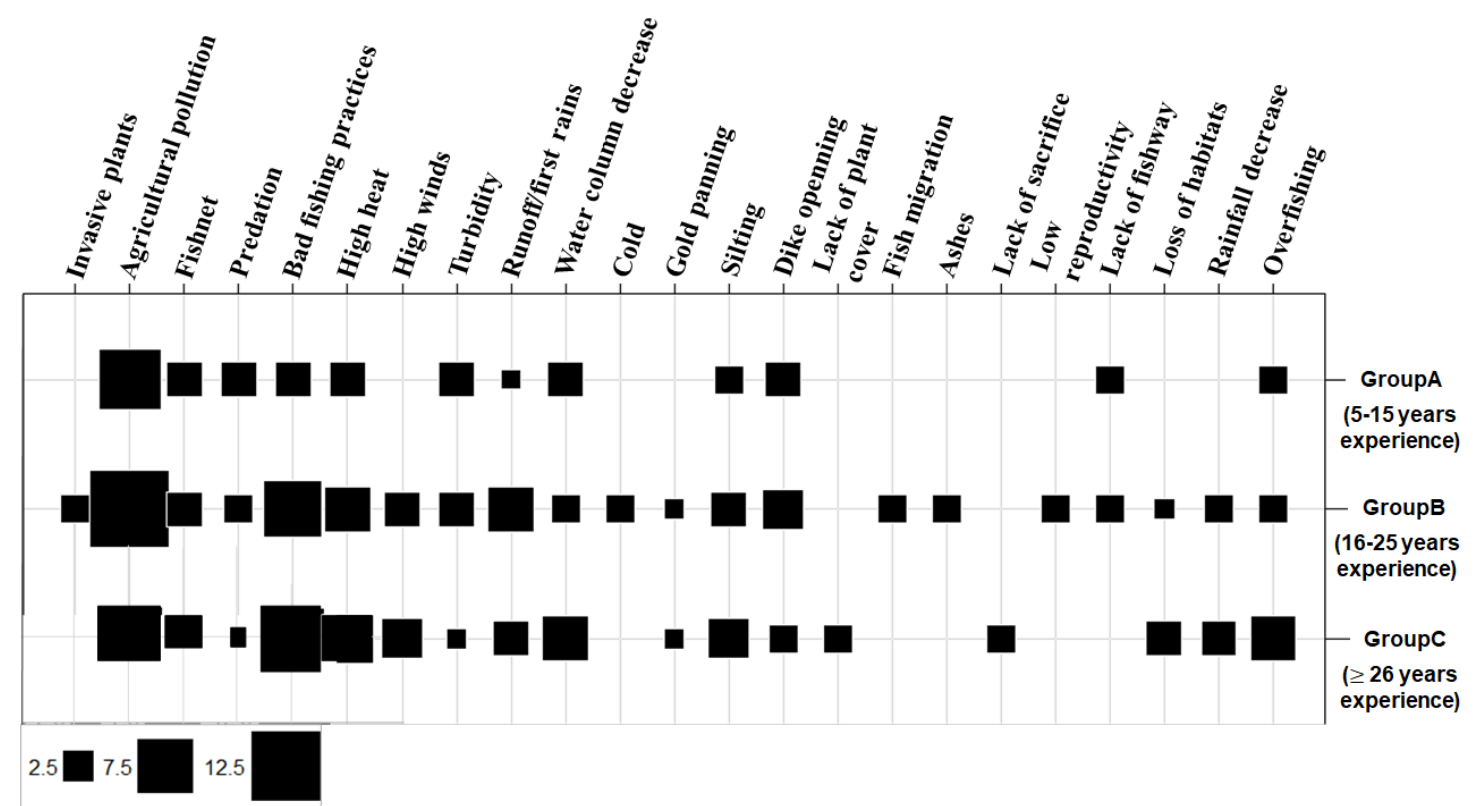

Figure 4. Indicators of pressures perception' according to the experience of the fishermen.

years of experience (at least 16 years or more) tend to perceive more threats, and are the ones indicating more perception indicators.

Figure 5 is showing some pressures observed in the field during the sampling period.

Thirteen (13) pressures were underlined as causes of fish mortality against 17 pressures recognized as factors of fish extinction (Figure 6). Seven threats were cited by fishermen interviewed as causing both mortality and extirpation of fish in water bodies. These were agricultural pollution, poor fishing/water harvesting practices, increased temperature, decreased water volume, high winds, and predation. This high number of common pressures as well as those that may cause fish extinction could be explained by the fact that mortality pressures lead to long-term extinction. 

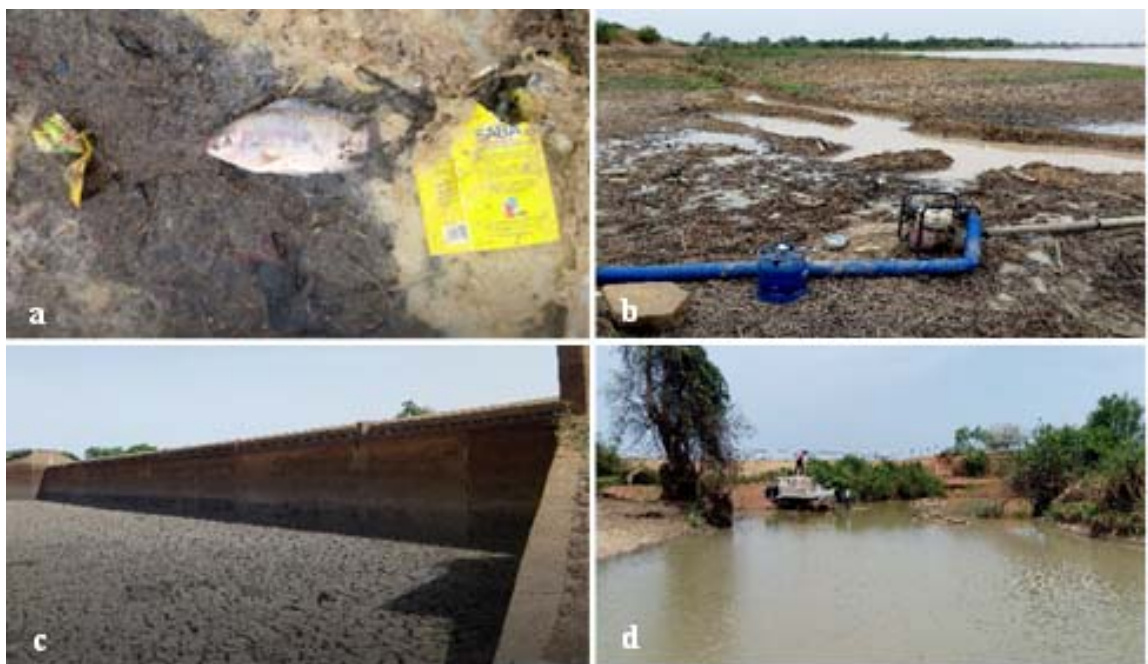

Figure 5. Images of some pressures observed in the field. (a) Deposition of organic matter and detergent observed at Arzoum Baongo; (b) Pumping water for irrigation in Konioudou reservoir; (c) Dewatered reservoir in Koubri area; (d) Pumping water in Naba Zana for construction.

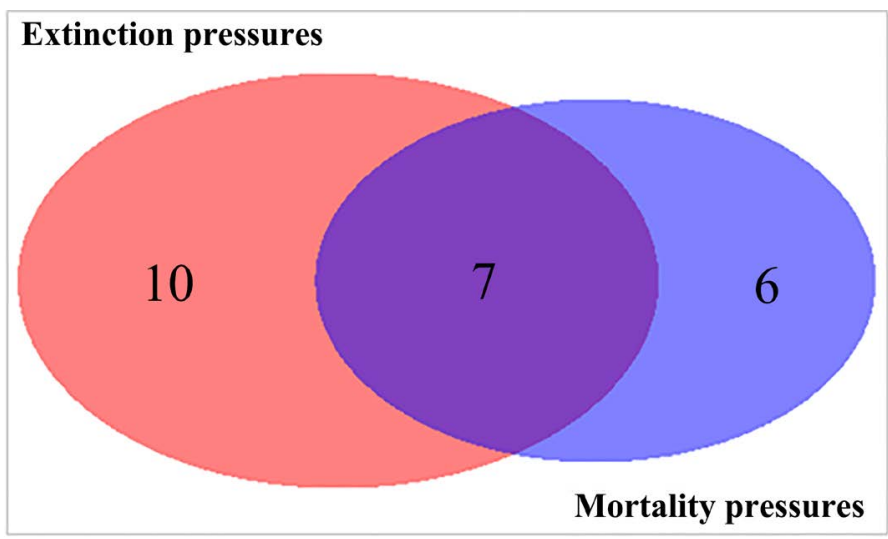

Figure 6. Venn diagram showing mortality and extinction pressures according to fishermen interviewed.

\subsection{Causes of the Drop in Water Level}

Of the 19 sites visited, only fishermen in Samandeni Reservoir did not experience a decrease in water level. According to fishermen from other fisheries interviewed, nine pressures were listed as potentially causing the decrease in water column (Figure 7). The main causes of this decrease in water level in the reservoirs would be silting $(84.21 \%)$, pumping for irrigation, buildings and public works $(31.58 \%)$, strong winds $(21.05 \%)$ as well as strong heat with its corollary of water evaporation (21.05\%).

\subsection{Causes of Fish Mortality}

The fishermen interviewed in the 19 reservoirs admitted to seeing dead fish in the reservoir at a certain time of year. In terms of the causes of this fish mortality, twelve pressures (Figure 8) were cited by the fishermen, the most recurrent 


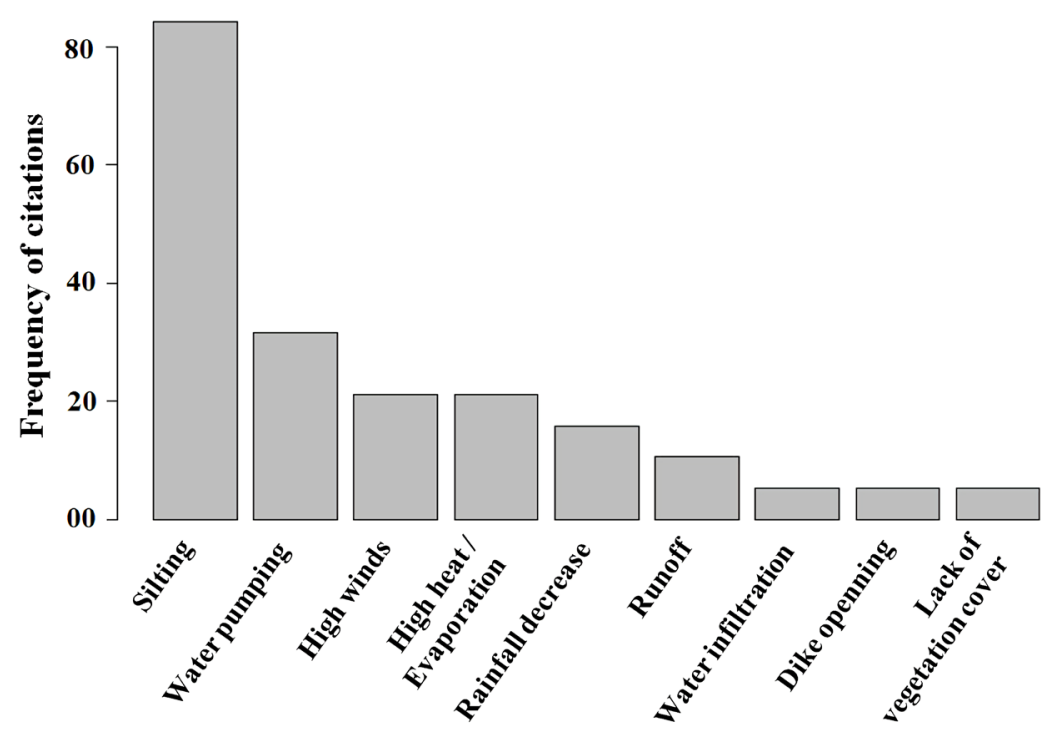

Figure 7. Main pressures affecting water column decrease.

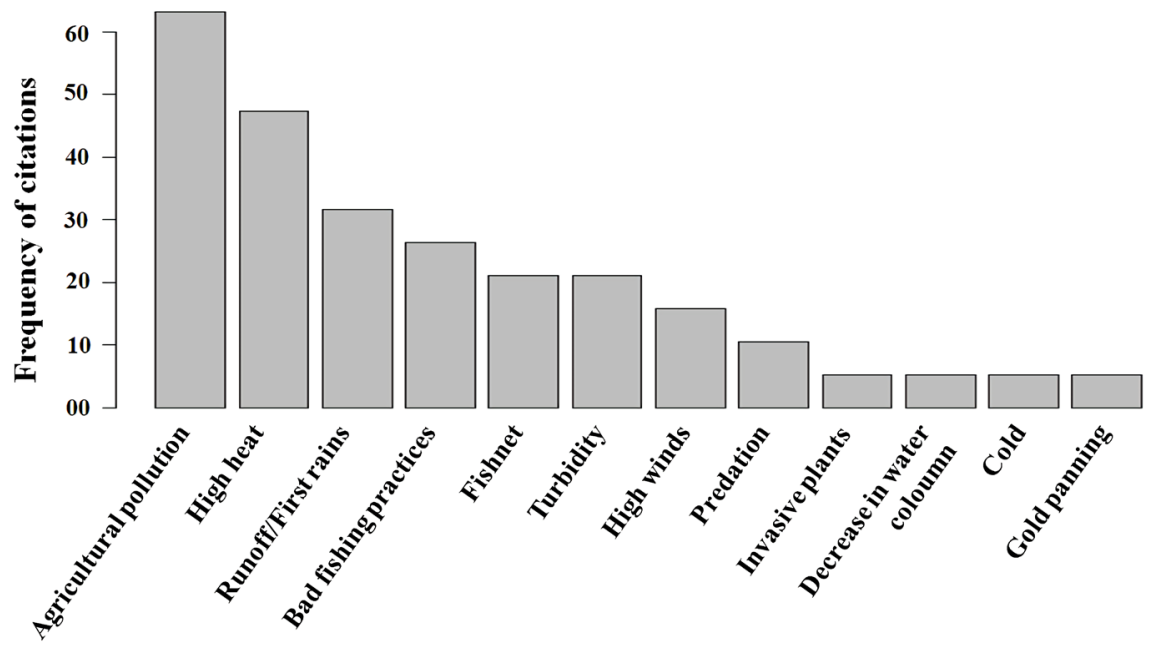

Figure 8. Main causes of fish mortality according to fishermen.

of which are Agricultural pollution (70.15\%), high temperatures (48\%), the first rains (32.12\%) and poor fishing practices (25\%). At none of the sites was natural mortality mentioned.

During the survey, dead fish carcasses were observed in the field (Figure 9).

The analysis of pressures by site shows that the Koubri reservoirs are the most affected by the maximum pressures. These include the Naba Zana and Arzoum Baongo reservoirs, which each recorded $69 \%$ and $54 \%$ of mortality pressures respectively (Figure 10).

The main groups of fish affected by this mortality are Cichlidae and Mormyridae. According to the fishermen, the factors influencing fish mortality vary depending on the group of fish considered. Figure 11 shows that the death of Mormyridae could be explained by several variables such as bad fishing practices, high winds, high heat, deposition of pots, turbidity and cold. On the other 


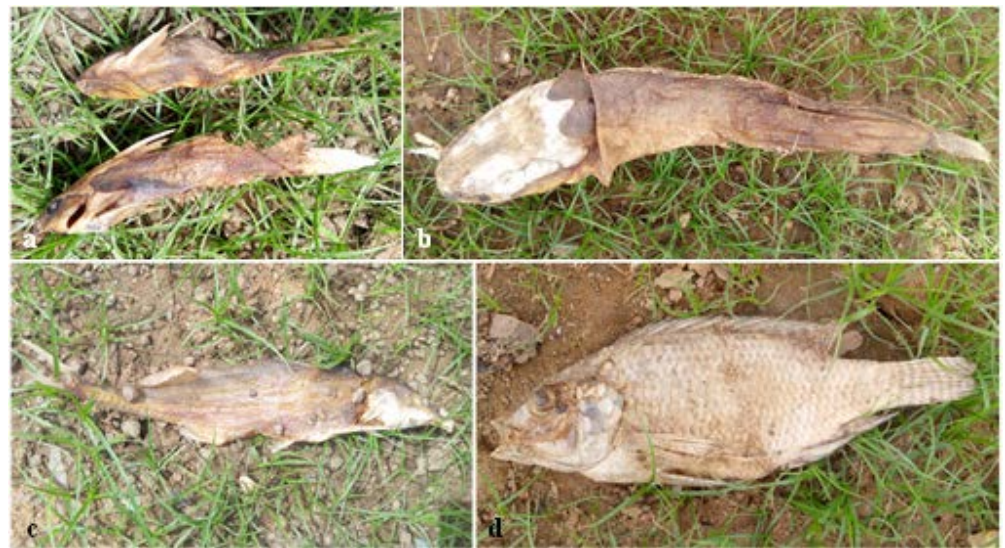

Figure 9. Images of some dead fish observed in the field. (a) Chrysichthys; (b) Clarias; (c) Mormyrus rume; (d) Oreochromis niloticus.

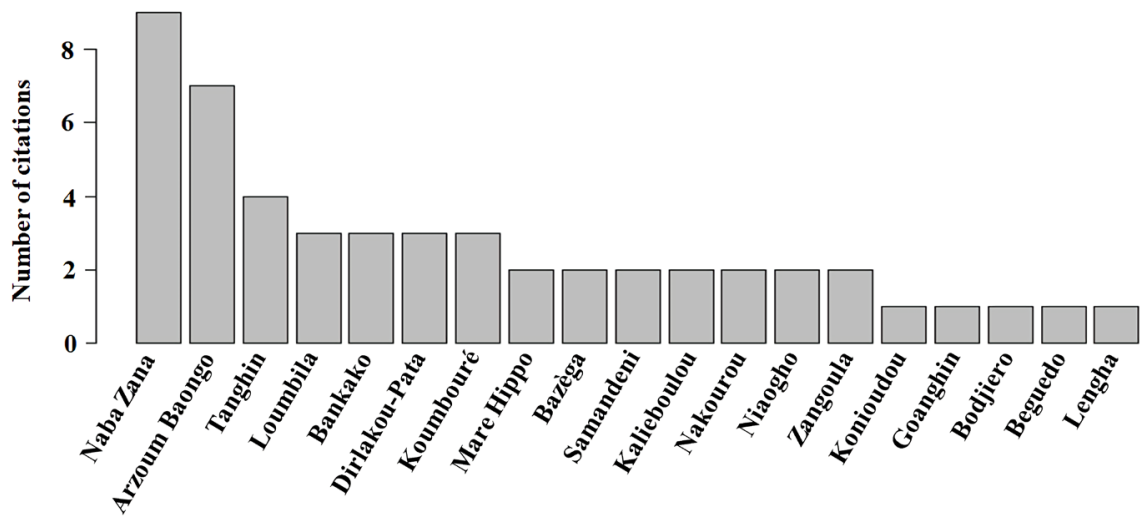

Figure 10. Number of pressures cited by site.

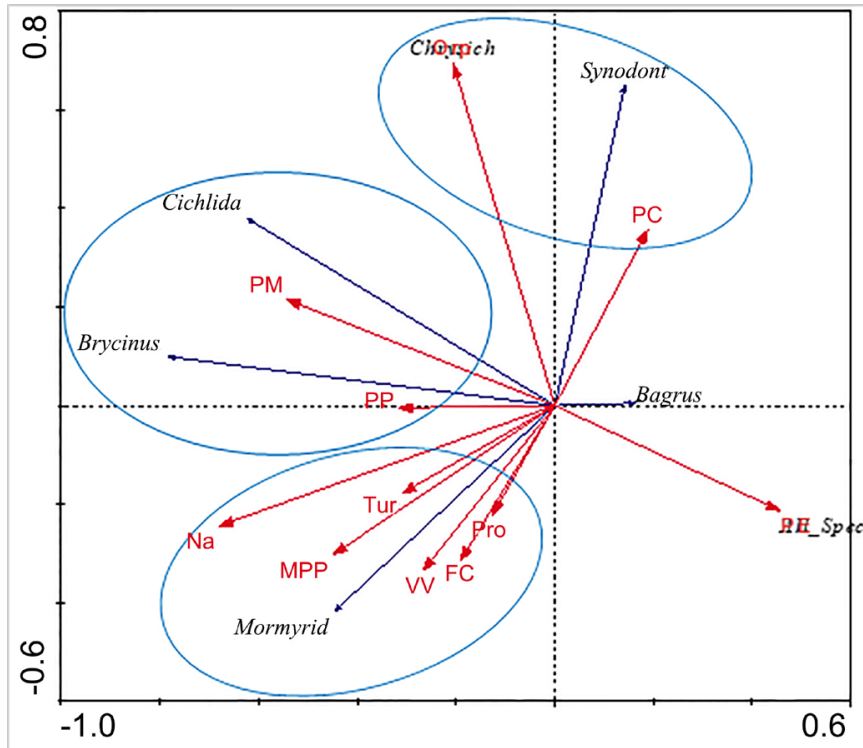

Figure 11. RDA showing the correlation between fish communities and environmental variables. Legend: PM. Agricultural pollution; Tur. Turbidity; Fro. Cold; FC. High heat; PE. Invasive plants; Na. Fishnet; MPP. Bad fishing practices; VV. High winds; Orp. Gold panning; PC. Predation; PP. First rains. 
hand, the Cichlidae as well as the fish of the genus Brycinus are mainly threatened by marsh pollution and drainage from the first rains. Gold mining residues would cause the death of fish of the genus Chrysichthys while the genus Synodontis would be victim of predation pressures. In addition, the presence of invasive plants could cause the death of any fish species.

According to the fishermen interviewed, the period of fish mortality is generally at the beginning of the rainy season. A total of $65 \%$ of the fishermen stated that fish die just after the first rains of the winter season, while $23 \%$ of the fishermen explain this mortality by the impact of the heat waves of the warm period of the year (March, April, May).

\subsection{Causes of the Fish Extinction}

According to the fishermen interviewed, there are different types of pressures that are causing the extinction of certain groups of fish. Among the pressures most cited by the fishermen are agricultural pollution (48.12\%), the drop in water levels in the reservoirs (38.72\%), as well as overfishing, the opening of the dike and silting up with $32.15 \%$ frequency of citations (Figure 12). Next to these, we note the rare pressures that were cited only once with a frequency of $5.26 \%$. These are predation, low reproductivity, lack of sacrifice, increase of water temperature, loss of habitat and high winds. The water temperature increase, although recognized as one of the main factors that can lead to the death of fish, is considered by few fishermen as being the cause of the fish extinction.

The main species affected by this loss are Lates niloticus, Heterotis niloticus and fish of the genus Hydrocynus. These fish were cited respectively by $65 \%$, $20 \%$ and $45 \%$ of the focus groups as being endangered in the reservoirs.

The analysis of pressures by site shows pressure numbers ranging from 0 (Samandeni and Nakourou) to 5 for some sites in Bagre such as Bankako and Dirlakou (Figure 13).

The redundancy analysis (Figure 14) allowed the categorization of endangered

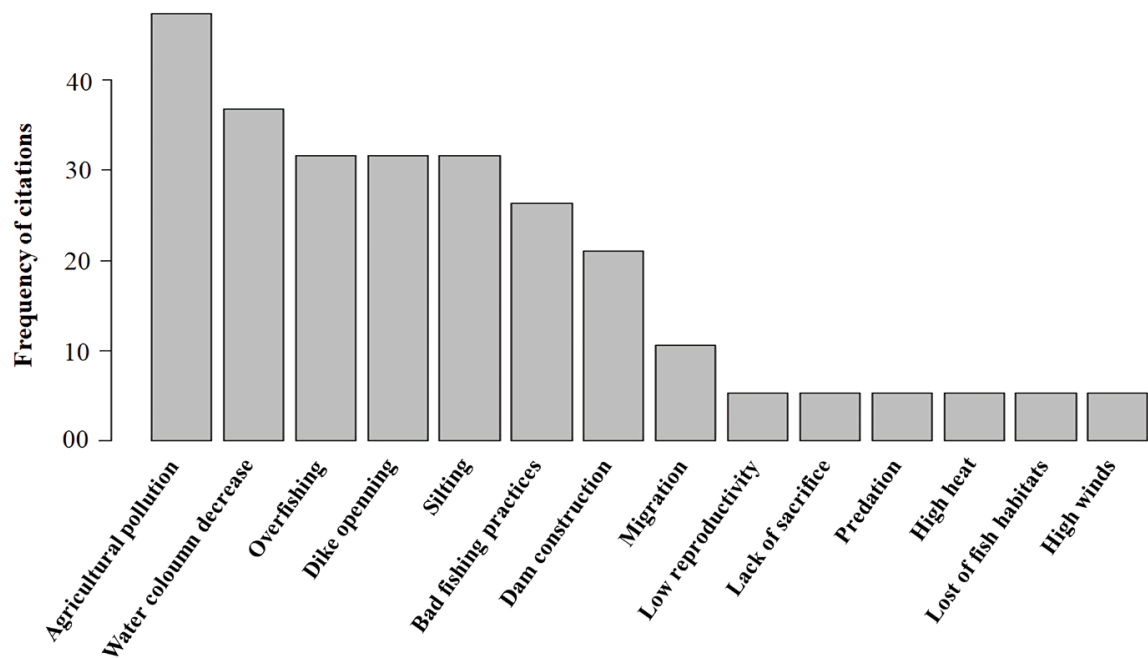

Figure 12. Pressures of fish extinction according to interviewed fishermen. 


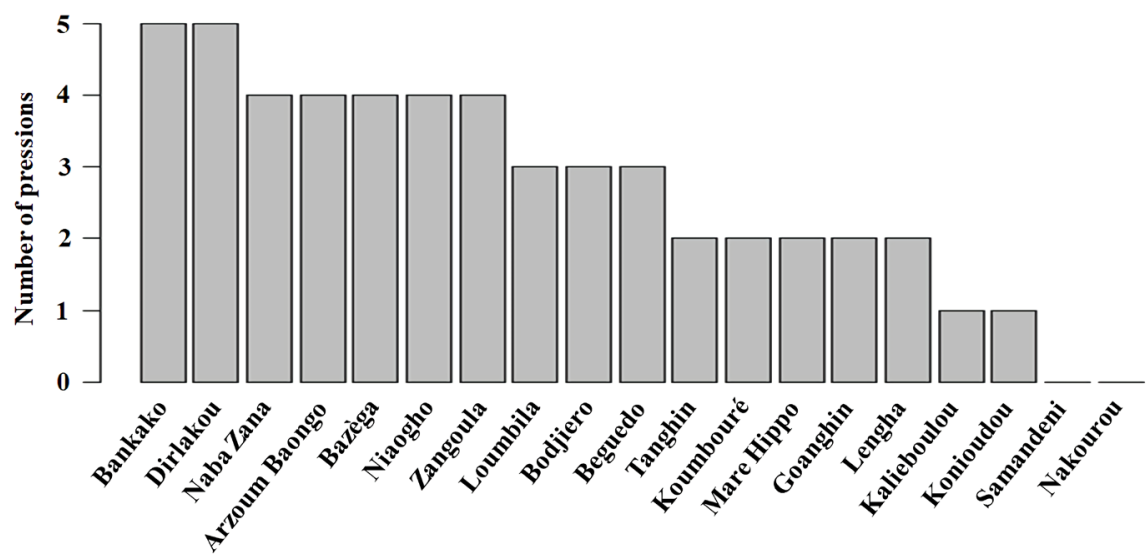

Figure 13. Number of pressures cited by site.

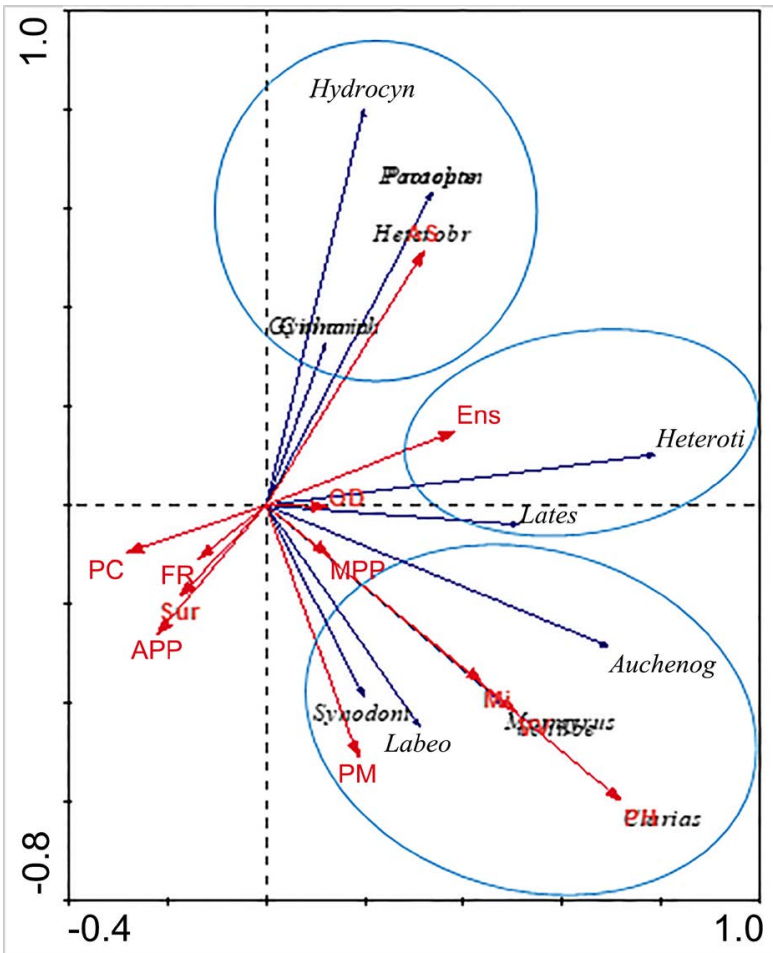

Figure 14. RDA showing correlation between causes of fish extinction and fish communities. Legend: Ens. Silting; OD. Dike opening; Mi. Migration; PM. Agricultural pollution; Sur. Overfishing; FR. Low reproductivity; MPP. Bad fishing practices; VV. High winds; PH. Loss of habitats; APP. Lack of fish pass; PC. Predation; AS. Absence of sacrifice.

fishes according to the different pressures cited by the fishermen. Thus, fish of the genus Synodontis, Auchenoglanus, Clarias, Labeo and Mormyrus would be endangered at some sites due to pressures such as loss of habitats ( $\mathrm{PH})$, high winds (VV), Agricultural pollution (PM) and migration (Mi). Sites where Heterotis niloticus and Lates niloticus are extirpated are mainly due to silting (Ens). Other species of the genus Hydrocynus, Protopterus and Heterobranchus are also believed to be endangered in some reservoirs due to pressures such as Absence of sacrifice (AS). 


\subsection{Adaptation and Management Strategies}

When asked about the adaptation measures of fishermen in the face of various environmental changes, 11 measures including suggestions were cited by them (Figure 15). The main adaptation measure according to them remains the Training, Awareness and Compliance (TAC).

\section{Discussion}

Fish resources in Burkina Faso are impacted by climate change and anthropic pressures and fishermen are aware of this situation. Some studies have already mentioned same perception by local farmers in Burkina Faso [18] [19]. This study is a contribution to monitoring the effects of global change at the local level and the related adaptation strategies by fishermen in Burkina Faso particularly in Volta basin. The perception indicators were correlated with the professional experience of the fishermen surveyed. Then, although the number of threats perceived does not seem to be correlated to the age group, it can be noted that the type of threat is a function of the age group of the fishermen. This was confirmed by the Kruskall Wallis test, which showed that there was a statistically significant difference in the perception of the different pressures, whereas the difference in terms of the number of pressures perceived by each of the three age groups was not significant. Similar work had also been done by Nago et al. [20], Kaboré et al. [21] and Hounkponou et al. [22]. In the researches of Nago et al. the groups of respondents were analyzed according to the types of perception determinants cited. Concerning the research of Kaboré et al. it was mentioned the Farmers' perceptions of climate change, environmental impacts and endogenous adaptive strategies in the North Central of Burkina Faso. While, the work of Hounkponou et al. was about correlating the factors determining perception and the ages of the respondents on the one hand and the coping strategies in relation

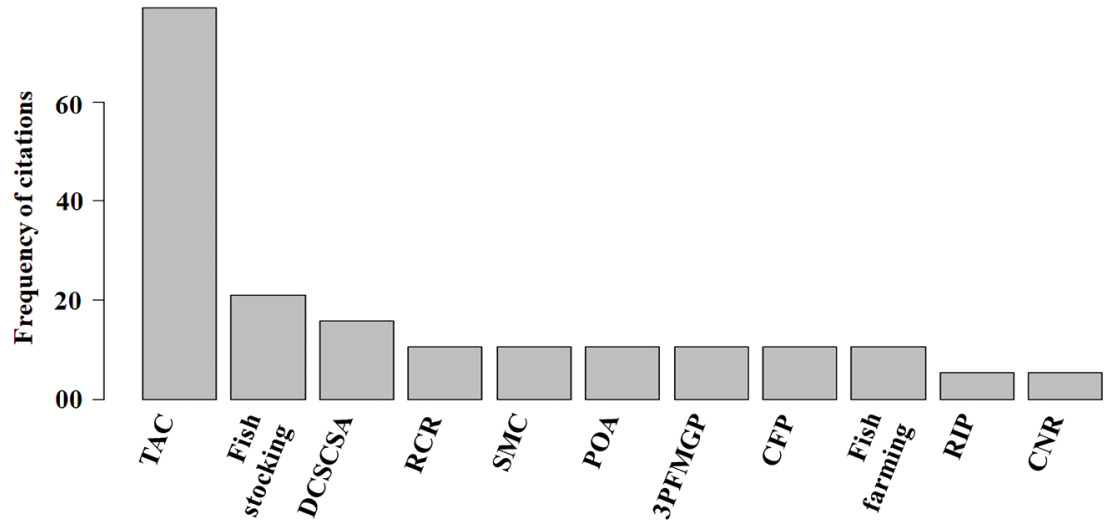

Figure 15. Fishermen adaptation strategies and suggestions. Legend: TAC. Training, Awareness and Compliance; DCSCSA. Dam Closure during Spawning and Creation of Spawning Areas, RCR. Reservoir Cleaning and Repair; SMC. Strengthening Monitoring Committees; POA. Performing Other Activities; 3PFMGP. Prohibition of Pumping, Poor Fishing and Market Gardening Practices; CFP. Creation of fish pass; RIP. Removal of Invasive Plants; CNR. Creation of New Reservoirs. 
to the level of prosperity on the other. The data collected during this study were mainly pressures causing the death and/or the disappearance of fish in the long term and fish which are concerned by the, factors causing water column fluctuation. The decrease in the water column of the reservoir could be explained by the consequences of climate change such as the decrease in rainfall [9] as well as the silting due to vegetable farming in the reservoir or around it. We could also note the effect of wind and water erosion; this is even more plausible for certain sites like Zangoula in Bagré reservoir where the northern part of the reservoir is devoid of any plant cover. Agricultural and electrical activities had already been reported by fishermen in Mali as being responsible for the decrease in floodings in the Inner Niger Delta [9]. Regarding the rise of reservoirs water temperature, in addition to the impact of climate change, Kyle et al. have shown that other variables such as solar radiation, the rising air temperature and plant cover could also increase the temperature of aquatic environment [23]. Arimoro et al. showed a strong positive correlation between the temperature of water and the temperature of ambient air [24].

\section{On the decrease of the water level}

The decrease in the water column of the reservoir could also be explained by the impacts of climate change such as the decrease in precipitation [9], evaporation due to the increase of temperature [25] as well as silting due to market gardening in or around the reservoirs. The effect of wind and water erosion could also be noted. Agricultural and electrical activities have been reported by fishermen in Mali to be responsible for reduced flooding in the Inner Niger Delta [9]. In Ghana, Laube et al. found a decrease of about $10 \%$ in mean annual rainfall across the Volta Basin, of which our study area is a part [26].

In terms of increasing water temperature in reservoirs, in addition to climate change impacts, it is showed that other variables such as solar radiation, increased air temperature, and lack of vegetation cover could also increase the temperature of the aquatic environment. Arimoro et al. have also showed a strong positive correlation between water temperature and ambient air temperature [24]. In a recent study, $72 \%$ and $87 \%$ of the surveyed households respectively informed about the increase in seasonal temperatures as well as the decrease in rainfall in their study sites (in Eastern Ghana and Southwestern Burkina Faso) [27].

\section{On fish mortality}

Seasonal mortality of fish concerns mainly the Mormyridae, Cichlidae and Mochokidae families'. Of all the species subject to seasonal mortality, species of the Mormyridae family are the most affected. As for the variables that would cause this mortality, the main ones would be marsh pollution, water temperature increase, first rains and bad fishing practices. Previous studies have shown a positive correlation between rising temperatures and mortality in human populations in Nouna [28]. It could be the same effect with aquatic communities and particularly, with fish fauna. According to the fishermen's groups interviewed, 
Mormyridae are a group of fish with high fat content and therefore vulnerable to large increases in water temperature. In addition, studies have also highlighted their status as intolerable species [29]. Other studies have shown that changes in water temperature and dissolved oxygen are problematic for aquatic organisms such as fish [30]. Therefore, these changes in temperature and dissolved oxygen can lead to fish death [31]. There is little data on the $\mathrm{pH}$ range of Mormyrops anguilloides. However, since its thermal preferences are very low and vary between $22^{\circ} \mathrm{C}$ min and $24^{\circ} \mathrm{C}$ max (www.fishbase.org), this could explain its inability to adapt to large temperature variations such as high heat during hot periods. In addition, it is a species that prefers deep and calm waters. Arimoro et al. [24] also showed that Mormyridae, like species of many other families such as Schilbeidae, Clariidae, Bagridae, among others, are very sensitive species to organic pollution. Indeed, the first rains are likely to drain household waste such as very basic ashes that could degrade the quality of the receiving ecosystem. Pesticides used in market gardening and agriculture would also contribute to deteriorate the quality of aquatic ecosystems with, as a corollary, the death of fish [32]. Some authors have also shown that the agricultural method could have negative effects on fisheries production [33]. Indeed, agricultural residues such as nitrogen derivatives (ammonium) can, at certain concentrations, lead to fish death [34].

\section{On the disappearance of fish}

Pressures causing fish extinction frequently cited by fishermen include the opening of the dike resulting in fish migration to Ghana. Indeed, the construction of dams without fishways constitutes a barrier that prevents the migration of fish from downstream to upstream reservoirs. Others pressures are also cited by fishermen. These were poor fishing practices and pesticide pollution. In fact, the effects of pollution from agriculture on fish could be indirect by causing increased siltation and reduced dissolved oxygen availability [35]. In 2016, Lam et al. concluded after a study in coastal West African countries that the rate of current fishing pressure would result in declining fish stocks [36]. Among the endangered fish species highlighted in this study, some species such as Heterotis niloticus and Lates niloticus had already been reported by fishermen in the Sahelian Lake Higa in 2012 as having disappeared from their fishing grounds [16]. Codjo, et al. in a study conducted in Lake Toho in southern Benin had also shown an extinction of large fish in general and species of the genus Hydrocynus, Heterotis, Clarias and Gymnarchus in particular [37]. Other studies have also highlighted the adverse effect of human activities on fish fauna [38] [39].

\section{Other fish stressors and limitations of pressures cited}

Among the fish stressors, a group of fishermen from Beguédo (in the upstream part of Bagré reservoir) mentioned the beating of the water not as a stressor but rather as a factor responsible for the concealment or burying of fish. According to these fishermen, the beating of the water cannot stress the fish but only causes a temporary modification of their habitat. This shows a lack of knowledge about the effects of certain fishing practices. Other fishermen also 
cited the opening of the dam gates during the flood period as a stressful variable, although this seems normal. In addition, the lack of a fishway downstream of the dam could explain the lack of fish return upstream. This again shows that some fishermen are unaware of fish stressors. However, for the vast majority of fishermen, beyond their knowledge of the harmful environmental and anthropogenic pressures on ichthyofauna, we note that they are also aware of the manifestations of climate change. A study by Nielsen and Reenberg [40] showed the perception of the same climatic variables by local populations located in the Burkinabe Sahel.

The pressures perceived by fishermen are found in the literature. Indeed, in several previous works carried out in Burkina Faso [25] [41] [42], pressures such as pesticide pollution, dam construction, overfishing, extreme weather events, temperature rise, evaporation and climate change have been cited as influencing water bodies as well as aquatic resources. A sociological study by Ayeri et al. in Kenya also showed that local stakeholders perceive the effects of climate change [43]. These include decreasing rainfall, increasing temperature, increasing frequency and intensity of high winds, the occurrence of famine in human populations and diseases in animals.

In addition, the work of Coulibaly et al. showed that the ability of fish to harbor certain parasites constitutes a threat to both the fisheries resource and a public health problem [44]. Yao et al. in Ivory Coast [45] and Rindoria [46] also demonstrated that fishery resources were negatively impacted by household waste and microbiological pollution. At none of the sites surveyed was parasitism reported as a pressure on fish resources. Several other studies conducted at the local level have shown that fish are hosts to parasites [47]-[52]. Thus, fishermen appear to be unaware of the effect of parasitism on the health status of fish.

\section{Adaptation measures and management strategies}

From the interviews conducted, adaptation is mainly through training, awareness and compliance. This shows the low resilience of fishermen to the adverse effects of climate change. In addition, other studies carried out in other countries have proposed adaptation and management measures. These include combating soil erosion through reforestation, increasing the carrying capacity of reservoirs [53], promoting and introducing adapted fish species [54] or using regulated nets and engaging in other income-generating activities [37]. On the national level, adaptation measures in the face of the adverse effects of changes such as the construction of water reservoirs has also been undertaken since the second half of the 20th century [1]. In addition, exchanges with resource persons have shown that fishermen migrate according to the availability of fish resources to other localities. This is further verified by the fact that some studies such as Henry et al. explained that migratory flows would be justified by a population adaptation strategy to climate change [55].

\section{Conclusion}

The fishery resources of Burkina Faso are affected negatively by environmental 
variables change. This study allowed us to assess the endogenous knowledge of fishermen in the Volta Basin with regard to the environmental and climatic impact on the lakes ichthyofauna. We were also able to establish the frequency of the various pressures and inventory the most endangered fish species. The data collected confirms our research hypothesis, namely, that fishermen perceive the nature and intensity of the pressures exerted on the ichthyological fauna in the basin level. Fishermen noted a decrease in the quantity and quality of fish catches due to the various stresses. These consequences will be all the more important in the future if no mitigation and/or adaptation measures are taken. However, some fishermen ignore the impact of certain pressures on the fish fauna. Therefore, it is important that measures are taken by decision-makers to promote the sustainable management of fishery. These include 1) taking fishways into account when building dams, 2) strengthening the technical skills of fishermen, 3) supporting and equipping fishery managers and 4) raising the awareness of the less well-equipped actors about the harmful effects of bad fishing practices. Finally, this study contributes to identify the different pressures on fisheries that are perceived by the fishermen of Burkina Faso and particularly those of our study sites.

\section{Acknowledgements}

The authors are grateful to the Sustainable Management of Water and Fish Resources in Burkina Faso (SUSFISH-plus) project which funded a part of the fieldwork. Funded itself by the Austrian Partnership Programme in Higher Education and Research for Development (APPEAR), this project aims to establish sustainable fisheries and water management through the improvement of higher education and governance in Burkina Faso. The authors are also grateful to fishermen who accepted to be interviewed and shared their knowledge about fisheries treats with them.

\section{Conflicts of Interest}

The authors have not declared any conflict of interests.

\section{References}

[1] Ouédraogo, M., Barry, S., Zougmoré, R.B., Partey, S.T., Somé, L. and Baki, G. (2018) Farmers' Willingness to Pay for Climate Information Services: Evidence from Cowpea and Sesame Producers in Northern Burkina Faso. Sustainability, 10, Article No. 611. https://doi.org/10.3390/su10030611

[2] Baptist, F., Guillon, M., Poulet, N., Séon-Massin, N., Fahrner, G., Gamboa, B., Buisson, L., Grenouillet, G., Comte, L., Lassalle, G., et al. (2014) Anticiper l'impact du changement climatique sur les peuplements de poissons. In: Baptist, F., Poulet, N. and Séon-Massin, N., Eds., Les poissons deau douce à Pheure du changement climatique état des lieux et pistes pour Padaptation, Office national de l'eau et des milieux aquatiques, Paris, 131.

[3] Daufresne, M., Lengfellner, K. and Sommer, U. (2009) Global Warming Benefits the 
Small in Aquatic Ecosystems. Proceedings of the National Academy of Sciences of the United States of America, 106, 12788-12793. https://doi.org/10.1073/pnas.0902080106

[4] IPCC (Intergovernmental Panel on Climate Change) (2007) Climate Change 2007: Synthesis Report. Contributing of Working Groups I, II and III to the Fourth Assessment Report of the Intergovernmental Panel on Climate Change [Core Writing Team, Pachauri, R.K and Reisinger, A. (Eds.)]. Intergovernmental Panel on Climate Change, Geneva.

[5] Gros, P. (2014) La pêche, une activité ancestrale en mutation. Cahiers Agricultures, 23, 4-17. https://doi.org/10.1684/agr.2014.0678

[6] Adite, A., Winemiller, K.O. and Fiogbe, E.D. (2005) Ontogenetic, Seasonal, and Spatial Variation in the Diet of Heterotis niloticus (Osteoglossiformes: Osteoglossidae) in the Sô River and Lake Hlan, Benin, West Africa. Environmental Biology of Fishes, 73, 367-378. https://doi.org/10.1007/s10641-004-5563-9

[7] FAO (Food and Agriculture Organization of the United Nations) (2007) Adaptation to Climate Change in Agriculture, Forestry and Fisheries: Perspective, Framework and Priorities. Food and Agriculture Organization of the United Nations, Rome.

[8] Dialla, Z., Tassembedo, M. and Micha, J.-C. (2016) Mode of Operation and Sustainability of Oreochromis niioticus (Linnaeus, 1758), Clarias gariepinus (Burchell, 1822) and Gymnarchus niloticus (Cuvier, 1829) Fisheries in the Sourou Dam Lake (Burkina Faso). Tropicultura, 34, 350-360.

[9] Fossi, S., Barbier, B., Brou, Y.T. and Kodio, A. (2012) Perception sociale de la crue et réponse des pêcheurs à la baisse de l'inondation des plaines dans le Delta Intérieur du Niger, Mali. Territoire en mouvement Revue de géographie et aménagement, 14-15, 55-72. https://doi.org/10.4000/tem.1739

[10] Zampaligré, N.L., Dossa, H. and Schlecht, E. (2014) Climate Change and Variability: Perception and Adaptation Strategies of Pastoralists and Agro-Pastoralists across Different Zones of Burkina Faso. Regional Environmental Change, 14, 769-783. https://doi.org/10.1007/s10113-013-0532-5

[11] Sanfo, S., Barbier, B., Dabiré, I.W.P., Vlek, P.L.G., Fonta, W.M., Ibrahim, B. and Barry, B. (2017) Rainfall Variability Adaptation Strategies: An Ex-Ante Assessment of Supplemental Irrigation from Farm Ponds in Southern Burkina Faso. Agricultural Systems, 152, 80-89. https://doi.org/10.1016/j.agsy.2016.12.011

[12] Sanfo, S., Fonta, W.M., Diasso, U.J., Nikiéma, M.P., Lamers, J.P.A. and Tondoh, J.E. (2017) Climate- and Environment-Induced Intervillage Migration in Southwestern Burkina Faso, West Africa. Weather, Climate, and Society, 9, 823-837. https://doi.org/10.1175/WCAS-D-16-0065.1

[13] Ouedraogo, I. (2010) Land Use Dynamics and Demographic Change in Southern Burkina Faso. Swedish University of Agricultural Sciences Alnarp, Umeå.

[14] Dixon, A.B. (2008) Wetlands and Indigenous Knowledge in the Highlands of Western Ethiopia. In: Wiegandt, E., Eds., Mountains. Sources of Water, Sources of Knowledge, 31, 197-210. https://doi.org/10.1007/978-1-4020-6748-8 12

[15] Blanc, J. (2009) Savoirs relationnels et 'engagement' avec le vivant: Les dimensions oubliées du métier d'éleveur? Natures Sciences Sociétés, 17, 29-39.

https://doi.org/10.1051/nss/2009005

[16] Ouedraogo, R., Soara, A.E. and Zerbo, H. (2015) Caractérisation du peuplement piscicole du réservoir de Boalin, Ziniaré (Burkina Faso) deux décennies après l'introduction de Heterotis niloticus. International Journal of Biological and Chemical Sciences, 9, 2488-2499. https://doi.org/10.4314/ijbcs.v9i5.20 
[17] Lévêque, C. and Paugy, D. (2006) Les poissons des eaux continentales africaines: Diversité, écologie, utilisation par l'homme. https://www.ird.fr

[18] Mertz, O., D’haen, S., Maiga, A., Moussa, I.B., Brabier, B., Diouf, A., Diallo, D., Da, E.D. and Dabi, D. (2012) Climate Variability and Environmental Stress in the Sudan-Sahel zone of West Africa. AMBIO, 41, 380-392.

https://doi.org/10.1007/s13280-011-0231-8

[19] Millogo, D., Nikiema, A., Koulibaly, B. and Zombre, N.P. (2017) Analyse de l'évolution de l'occupation des terres à partir de photographies aériennes de la localité de Loaga dans la province du Bam, Burkina Faso. International Journal of Biological and Chemical Sciences, 11, 2133-2143. https://doi.org/10.4314/ijbcs.v11i5.16

[20] Nago, S.G.A., Gnohossou, P., Sagbo, R.R.S. and Bokonon-Ganta, E. (2019) Perception du changement climatique et stratégies locales d'adaptation dans la pêcherie de la Réserve de Biosphère de la Pendjari, Bénin. Afrique Science, 15, 114-127.

[21] Kaboré, P.N., Barbier, B., Ouoba, P., Kiéma, A., Somé, L. and Ouédraogo, A. (2019) Perceptions du changement climatique, impacts environnementaux et stratégies endogènes d'adaptation par les producteurs du Centre-nord du Burkina Faso. VertigO_La revue électronique en sciences de lenvironnement, 19, 1-24.

https://doi.org/10.4000/vertigo.24637

[22] Hounkponou, S., Sagbo, R.R.S., Nago, S.G.A., Hounkpe, I.A. and Yabi, J.A. (2020) Perception et stratégies d'adaptation des producteurs et productrices de maïs de la commune de Dangbo face aux effets des changements climatiques. Revue Espaces, Cultures et Développement, 1, 105-124.

[23] Kyle, R.E. and Brabets, T.P. (2001) Water Temperature of Streams in the Cook Inlet Basin, Alaska, and Implications of Climate Change. In: Water-Resources Investigations Report, Vol. 2, U.S. Geological Survey, Alaska, No. 01-4109, 1-40. https://doi.org/10.3133/wri014109

[24] Arimoro, F.O., Ikomi, R.B. and Osalor, E.C. (2007) The Impact of Sawmill Wood Wastes on the Water Quality and Fish Communities of Benin River, Niger Delta Area, Nigeria. International Journal of Science \& Technoledge, 2, 1-12.

[25] Sanon, V.P., Toé, P., Revenga, J.C., El Bilali, H., Hundscheid, L.J., Kulakowska, M., Magnuszewski, P., Meulenbroek, P., Paillaugue, J., Sendzimir, J., Slezak, G., Vogel, S. and Melcher, A.H. (2020) Multiple-Line Identification of Socio-Ecological Stressors Affecting Aquatic Ecosystems in Semi-Arid Countries: Implications for Sustainable Management of Fisheries in Sub-Saharan Africa. Water, 12, Article No. 29. https://doi.org/10.3390/w12061518

[26] Laube, W., Schraven, B. and Awo, M. (2012) Smallholder Adaptation to Climate Change: Dynamics and Limits in Northern Ghana. Climatic Change, 111, 753-774. https://doi.org/10.1007/s10584-011-0199-1

[27] Boansi, D., Tambo, J.A. and Müller, M. (2017) Analysis of Farmers' Adaptation to Weather Extremes in West African Sudan Savanna. Weather Weather and Climate Extremes, 16, 1-13. https://doi.org/10.1016/j.wace.2017.03.001

[28] Diboulo, E., Sié, A., Rocklöv, J., Niamba, L., Yé, M., Bagagnan, C. and Sauerborn, R. (2012) Weather and Mortality: A 10 Year Retrospective Analysis of the Nouna Health and Demographic Surveillance System, Burkina Faso. Global Health Action, 5, Article No. 19078. https://doi.org/10.3402/gha.v5i0.19078

[29] Adou, E.Y., Blahoua, G.K., Bamba, M., Yao, S.S. and Kouamelan, P.E. (2017) Premières données sur l'inventaire du peuplement ichtyologique d'un lac ouest Africain situé entre deux barrages hydroélectriques: Lac d'Ayamé 2 (Côte d'Ivoire). Journal of Applied Biosciences, 110, 10808-10818. 
https://doi.org/10.4314/jab.v110i1.11

[30] Brunel, T. and Dickey-Collas, M. (2010) Effects of Temperature and Population Density on von Bertalanffy Growth Parameters in Atlantic Herring: A Macro-Ecological Analysis. Marine Ecology Progress Series, 405, 15-28. https://doi.org/10.3354/meps08491

[31] Poff, N.L., Brinson, M.M. and Day, J.W. (2002) Aquatic Ecosystems \& Global Climate Change-Potential Impacts on Inland Freshwater and Coastal Wetland Ecosystems in the United States. Pew Center on Global Climate Change, United States of America (USA), $57 \mathrm{p}$.

[32] Abaga, N.O.Z., Dousset, S., Munier-Lamy, C. and Billet, D. (2014) Effectiveness of Vetiver Grass (Vetiveria zizanioides L. Nash) for Phytoremediation of Endosulfan in Two Cotton Soils from Burkina Faso. International Journal of Phytoremediation, 16, 95-108. https://doi.org/10.1080/15226514.2012.759531

[33] Khoa, S.N., Lorenzen, K.A.I., Garaway, C., Chamsinhg, B., Siebert, D. and Randone, M. (2005) Impacts of Irrigation on Fisheries in Rain-Fed Rice-Farming. Journal of Applied Ecology, 42, 892-900. https://doi.org/10.1111/j.1365-2664.2005.01062.x

[34] Randall D.J. and Tsui, T.K.N. (2002) Ammonia Toxicity in Fish. Marine Pollution Bulletin, 45, 17-23. https://doi.org/10.1016/S0025-326X(02)00227-8

[35] Arthington, A.H., Dulvy, N.K., Gladstone, W. and Winfield, I.J. (2016) Fish conservation in Freshwater and Marine Realms: Status, Threats and Management. $A q$ uatic Conservation: Marine and Freshwater Ecosystems, 26, 838-857. https://doi.org/10.1002/aqc. 2712

[36] Cheung, W.W.L., Jones, M.C., Reygondeau, G., Stock, C.A., Lam, V.W.Y. and Frölicher, T.L. (2016) Structural Uncertainty in Projecting Global Fisheries Catches under Climate Change. Ecological Modelling, 325, 57-66.

https://doi.org/10.1016/j.ecolmodel.2015.12.018

[37] Codjo, V., Zannou, A. and Biaou, G. (2018) Baisse des ressources halieutiques du lac Toho au Sud du Bénin: Perceptions des pêcheurs et efficacité des pratiques de gestion et stratégies d'adaptation. Tropicultura, 36, 713-721.

[38] Rakotoambinima, S., Desprez, D., David, G., Bosc, P. and Le Roux, Y. (2009) Caractérisation des environnements écologiques et socio-économiques de la production piscicole continentale à Madagascar. Les Cah. d'Outre-Mer-Revue géographie Bordeaux, 62, 471-488.

[39] Poikane, S., Ritterbusch, D., Argillier, C., Bialokoz, W., Blabolil, P., Breine, J., Jaarsma, N.G., Krause, T., Kubecka, J., Lauridsen, T.L., Noges, P., Peirson, G. and Virbickas, T. (2017) Response of Fish Communities to Multiple Pressures: Development of a Total Anthropogenic Pressure Intensity Index. Science of the Total Environment, 586, 502-511. https://doi.org/10.1016/j.scitotenv.2017.01.211

[40] Nielsen, J. Ø. and Reenberg, A. (2010) Cultural Barriers to Climate Change Adaptation: A Case Study from Northern Burkina Faso. Global Environmental Change, 20, 142-152. https://doi.org/10.1016/j.gloenvcha.2009.10.002

[41] FAO (2017) Planning for Aquaculture Diversification: The Importance of Climate Change and Other Drivers. FAO Technical Workshop, 23-25 June 2016, 166 p.

[42] Lehmann, E., Fargues, M., Nfon Dibié, J.J., Konaté, Y. and de Alencastro, L.F. (2018) Assessment of Water Resource Contamination by Pesticides in Vegetable-Producing Areas in Burkina Faso. Environmental Science and Pollution Research, 25, 3681-3694. https://doi.org/10.1007/s11356-017-0665-Z

[43] Ayeri, O.S., Christian, V.R., Josef, E. and Michael, H. (2012) Local Perceptions and 
Responses to Climate Change and Variability: The Case of Laikipia District, Kenya. Sustainability, 4, 3302-3325. https://doi.org/10.3390/su4123302

[44] Coulibaly, N.D., Salembere, S. and Bessin, R. (1995) Infestation of Cichlids Fish by Larva of Clinostomum sp. in Kompienga Lake, Burkina Faso: A Threat for Halieutic Exploitation and Public Health. Cahiers Santé, 5, 189-193.

[45] Yao, A.A., Konan, M.K., Doumbia, L., Ouattara, A. and Gourene, G. (2019) Diversité et Structure du Peuplement Ichtyologique du Bassin Inférieur du Fleuve Comoé (Côte d'Ivoire). European Scientific Journal, 15, 244-268. https://doi.org/10.19044/esj.2019.v15n6p244

[46] Rindoria, N.M. (2016) Morphometric Analysis of Monogenean Parasites of Cichlid and Cyprinid Fish in Lake Naivasha, Kenya. Egerton University, Nä̈robi, 95 p.

[47] Boungou, M., Kabré, G.B., Sakiti, N.G., Marques, A. and Sawadogo, L. (2006) Description of Four New Myxosporean Species (Myxozoa: Myxosporea) from Genus Myxobolus, Fish Parasites of Burkina Faso, West Africa. Journal of Biological Sciences, 6, 861-867. https://doi.org/10.3923/jbs.2006.861.867

[48] Boungou, M., Kabre, G.B., Marques, A. and Sawadogo, L. (2008) Dynamics of Population of Five Parasitic Monogeneans of Oreochromis niloticus Linné, 1757 in the Dam of Loumbila and Possible Interest in Intensive Pisciculture. Pakistan Journal of Biological Sciences, 11, 1317-1323. https://doi.org/10.3923/pjbs.2008.1317.1323

[49] Kabre, G.B., Sakiti, N.G., Marques, A. and Sawadogo, L. (2002) Thelohanellus bicornei sp. n. (Myxosporea, Bivalvulida) a Gill Parasite of Labeo coubie Rüppel, 1832 (Osteichthyen cyprinidae) from Burkina Faso, West Africa. Parasite, 9, 219-223. https://doi.org/10.1051/parasite/2002093219

[50] Kabre B.G. and Petter, A.J. (1997) Camallanus polypteri n. sp. (Nematoda: Camallanidae) in Freshwater Fishes from Burkina Faso. Onderstepoort Journal of Veterinary Research, 64, 33-37.

[51] Sinaré, Y., Boungou, M., Ouéda, A., Mano, K., Kpoda, W.N., Sakiti, N.G. and Kabré, G.B. (2015) Occurrence of Tetracampos ciliotheca (Cestoda: Bothriocephalidea) in the Gall Bladder of Clarias anguillaris in Burkina Faso. African Journal of Aquatic Science, 40, 433-437. https://doi.org/10.2989/16085914.2015.1082900

[52] Amin, O.M., Evans, R.P., Boungou, M. and Heckmann, R. (2016) Morphological and Molecular Description of Tenuisentis niloticus (Meyer, 1932) (Acanthocephala: Tenuisentidae) from Heterotis niloticus (Cuvier) (Actinopterygii: Arapaimidae), in Burkina Faso, with Emendation of the Family Diagnosis and Notes on New Feature. Systematic Parasitology, 93, 173-191. https://doi.org/10.1007/s11230-015-9615-7

[53] Iglesias A. and Garrote, L. (2015) Adaptation Strategies for Agricultural Water Management under Climate Change in Europe. Agricultural Water Management, 155, 113-124. https://doi.org/10.1016/j.agwat.2015.03.014

[54] Shelton, C. (2014) Climate Change Adaption in Fisheries and Aquaculture-Compilation of Initial Examples. FAO Fisheries and Aquaculture Circular, Vol. 1088, Food and Agriculture Organization of the United Nations, Rome.

[55] Henry, S., Boyle, P. and Lambin, E. F. (2003) Modelling Inter-Provincial Migration in Burkina Faso, West Africa: The Role of Socio-Demographic and Environmental Factors. Applied Geography, 23, 115-136.

https://doi.org/10.1016/j.apgeog.2002.08.001 